\title{
Zygotic embryogenesis and empty seed formation in European larch (Larix decidua Mill.)
}

\author{
Branko SLOBODNÍK ${ }^{\mathrm{a} *}$, Helmut GUTTENBERGER ${ }^{\mathrm{b}}$ \\ ${ }^{a}$ Department of Phytology, Faculty of Forestry, Technical University in Zvolen, T. G. Masaryka 24, 96053 Zvolen, Slovakia \\ b Department of Plant Physiology, University of Graz, Schubertstraße 51, 8010 Graz, Austria
}

(Received 25 November 2003; accepted 22 November 2004)

\begin{abstract}
Zygotic embryo development and its influence on empty seed formation of the European larch (Larix decidua Mill.) was studied within a seed orchard in the Slovak Republic. Histological study revealed a fertilization date early June. Although embryogenesis was most intensive in June, fully morphologically differentiated embryos were observed no earlier than in the second half of July. Multiple fertilization and simple polyembryony were relatively rare but their frequencies correlated with the efficiency of pollination. Only a small percentage of developing embryos reached full maturity. Degeneration included suppressed embryos from polyembryony as well as normal embryos occupying the optimal position within the corrosion cavity of the female gametophyte. The mean proportion of fertilized ovules without a viable embryo was $61 \%$ after open pollination and as high as $88 \%$ after controlled selfing. In total, embryo degeneration reduced the potential full seed percentage by almost $40 \%$ and is therefore considered the most important cause of unsound seed development in European larch.
\end{abstract}

larch / embryo / embryogenesis / empty seed

Résumé - Embryogenèse zygotique et formation des graines vides chez le mélèze d'Europe (Larix decidua Mill.). Le développement des embryons zygotiques et son influence sur la formation des graines vides du mélèze d'Europe (Larix decidua Mill.) ont été observés en condition de verger à graines en République Slovaque. L'étude histologique révèle que la période de fécondation la plus fréquente est le début du mois de juin. Bien que l'embryogenèse soit la plus intensive en juin, les embryons morphologiquement les plus différenciés sont observés dans la deuxième moitié du mois de juillet. Même si la fécondation multiple et la polyembryonie simple sont relativement rares, elles sont corrélées avec une pollinisation abondante. Le pourcentage d'embryons développés est très faible. La dégénérescence a affecté les embryons opprimés de polyembryonie ainsi que les embryons ayant la position optimale dans le gamétophyte femelle. La moyenne des ovules fécondés ne présentant pas d'embryon vivant a atteint $61 \%$ après pollinisation libre et près de $88 \%$ d'ovules après autopollinisation contrôlée. En moyenne, la dégénérescence des embryons a réduit le pourcentage potentiel de graines pleines de presque $40 \%$ et c'est pourquoi elle est considérée comme la cause principale de la formation des graines vides chez le mélèze d'Europe.

mélèze / embryon / embryogenèse / graine vide

\section{INTRODUCTION}

European larch (Larix decidua Mill.) is a tree species with fast growth, valuable timber and a relatively high resistance to unfavourable environmental conditions and pests [35]. Despite the limited natural distribution, it is a frequent subject of introduction and breeding programmes over Europe and overseas $[8,10,16,21,25]$. Unfortunately, its natural and artificial regeneration is hampered by a high percentage of normalappearing but empty seeds.

Since pre-fertilization ovule development of Larix Mill. occurs regardless of the presence of pollen grains on the stigmatic micropyle [22, 24], insufficient pollination has been considered the general cause of this problem. According to our previous data [31], however, correlation between the efficiency of pollination and full seed percentage is relatively poor and it is therefore supposed that there exist additional factors affecting empty seed production.

In addition to the lack of pollination, other pre-zygotic events are known to influence mating success. These include pollination with non-viable pollen grains $[5,7,32]$, abnormal pre-fertilization development of the female gametophyte [18, $19,33]$ and disturbance of the pollination mechanism $[19,34]$.

Among post-zygotic events, the zygotic embryo development of larch is considered to be complex and vulnerable to failure $[13,14,18,19,30]$. Nevertheless, a closer look at postzygotic processes is warranted, one that focuses on the types of losses during embryo formation and maturation. On this

\footnotetext{
*Corresponding author: slobod@ vsld.tuzvo.sk
} 
account, further detailed studies of zygotic embryogenesis could contribute to understanding some mechanisms of unsound seed formation in European larch.

\section{MATERIALS AND METHODS}

Female strobili of European larch were collected in 1998 from four grafted plants in the "Kmet'ová" seed orchard in Central Slovakia. This orchard was established in 1973 and is composed of the vegetative progenies of plus trees from the regions of Sumiac (South-Eastern part of Low Tatra Mts., autochthonous population of European larch - all the clones marked with "Š") and Motycky (Western part of Low Tatra Mts., allochtonous provenance of uncertain origin - the clones marked with "M"). For the purpose of embryological research, representative individuals from the most fertile clones were chosen after previously controlling for the production of female generative buds.

Semi-thin sections $(\sim 1.5 \mu \mathrm{m}$ thick) were used for preparation of slides. Before the light microscopy studies, sampled ovules were deprived of integument and treated analogous to our previous papers $[33,34]$.

The zygotic embryogenesis process was compared by pollination method. In addition to exposing the female strobili to open pollination, self-pollination was tested: several branches containing both male and female generative structures were isolated together using waxed paper bags. Within the first three weeks of embryo development, 2025 ovules from each clone (in dependence on the mode of pollination) were assessed to measure the occurrence of simple polyembryony and degenerating embryos. The relationship between the pollination success and the frequency of simple polyembryony was studied by nonlinear correlation. Pollination efficiency was expressed by the mean number of pollen grains per pollinated ovule, quantified at the end of the pollination period and published in our earlier papers [31, 34].

\section{RESULTS}

\subsection{Embryo and seed development in European larch}

Sixteen-celled proembryos with four different layers were observed in early June, almost two months after the most intensive pollination and one week after pollen germination on the tip of nucellus. Initially (while the proembryo remained located at the chalazal end of fertilized archegonium), all four layers of the proembryo were of approximately equal size (Fig. 1a). By the consecutive suspensor's expansion (Fig. 1b), the embryonal group was pushed from the fertilized archegonium into the central region of the female gametophyte, where the corrosion cavity was formed by dissolution of megagametophyte cells. Given the relatively long distance of this displacement (about $1.3-1.5 \mathrm{~mm}$ ), a massive multicellular suspensor system was formed to make relocation of the embryonal tier possible and, concurrently, to keep its connection with the intracellular content of fertilized archegonium (Fig. 1c).

Formation and development of the non-differentiated multicellular (globular or ellipsoidal) embryonal mass were observed in the second and third week of June (Figs. 1c-1e). At the start of this phase of embryogenesis (a short time after displacement of the embryonal group to the central region of ovule), some of the four embryonal units of the former proembryo lagged behind and were suppressed (Fig. 1d).

When the non-differentiated embryo reached a length of about $350-400 \mu \mathrm{m}$, the first indications of histogenesis became
Table I. Results of testing the differences between the proportions of fertilized ovules with simple polyembryony depending on mode of pollination; $p_{1} ; p_{2}=$ proportions of fertilized ovules with simple polyembryony, $n_{1} ; n_{2}=$ sample sizes, $\varphi_{1} ; \varphi_{2}=$ transformed variables, $\varphi_{1}=\arcsin \sqrt{p_{1}} ; \varphi_{2}=\arcsin \sqrt{p_{2}}, t_{s}=$ test statistic of the equality of two percentages $\left(t_{s}=\left[\varphi_{1}-\varphi_{2}\right] / \sqrt{820.8 \cdot\left[1 / n_{1}+1 / n_{2}\right]}\right), z_{0.05} ; z_{0.01}$ $=$ critical values of normal distribution.

\begin{tabular}{lcccccc}
\hline Pollination & $p_{1} ; p_{2}$ & $n_{1} ; n_{2}$ & $\varphi_{1} ; \varphi_{2}$ & $t_{s}$ & $z_{0.05}$ & $z_{0.01}$ \\
\hline Open & $12.1 \%$ & 44 & 20.37 & & & \\
Self & $5.4 \%$ & 49 & 13.44 & & & 2.168 \\
\hline
\end{tabular}

observable. The earlier stages of this process progressed relatively quickly and, consequently, all of the basic structural units of the embryo were formed around late June. The total embryo length was approximately $1.1 \mathrm{~mm}$ and its maximal width (in the region of cotyledons) ranged between 350 and $400 \mu \mathrm{m}$. However, the morphological development was still incomplete because of further enlargement and elongation of the embryo. Its definitive size and dimensions were not observed before the second half of July, when the full-sized embryo was approximately 2.1-2.3 mm long and about $0.7 \mathrm{~mm}$ wide (Fig. 1f).

\subsection{Occurrence of simple polyembryony}

The percentage of ovules with two or more fertilized archegonia (i.e. simple polyembryony) ranged from 0 to $25 \%$ depending on the mode of pollination and the clone. Although the differences between open pollination and self-pollination were not significantly different statistically (Tab. I), the frequency of ovules with simple polyembryony correlated with pollination efficiency (defined as the mean number of pollen grains per pollinated ovule).

The frequency of simple polyembryony increased very markedly when the pollination efficiency reached 3-4 pollen grains per pollinated ovule (Fig. 2). However, the percentages of multiple fertilization and simple polyembryony became irregular when 4 to 8 pollen grains were observed on the stigmatic hairs. Therefore, the highest correlation coefficient $(r=0.94)$ was computed when the threshold value of 4 pollen grains per pollinated ovule was taken into consideration. Although the correlated variables consisted of a restricted number of cases, the $r$-value is significant at $\alpha=0.05$.

Nevertheless, the low rate of multiple fertilization does not correspond to the relatively high ascertained number of archegonia per ovule, which ranged from 2 to 5 with the mean values of individual clones ranging from 2.25 to 3.5 with a total weighted mean of 3.12 .

\subsection{Degenerating embryos}

Despite the relatively high proportion of fertilized ovules (on average, more than 50\%), only a few embryos achieved the stage of the full maturity. A great deal of embryos abnormal in appearance and showing consecutive degeneration were observed, especially in the phase of the non-differentiated multicellular embryonal mass (at about the mid-June), when the 

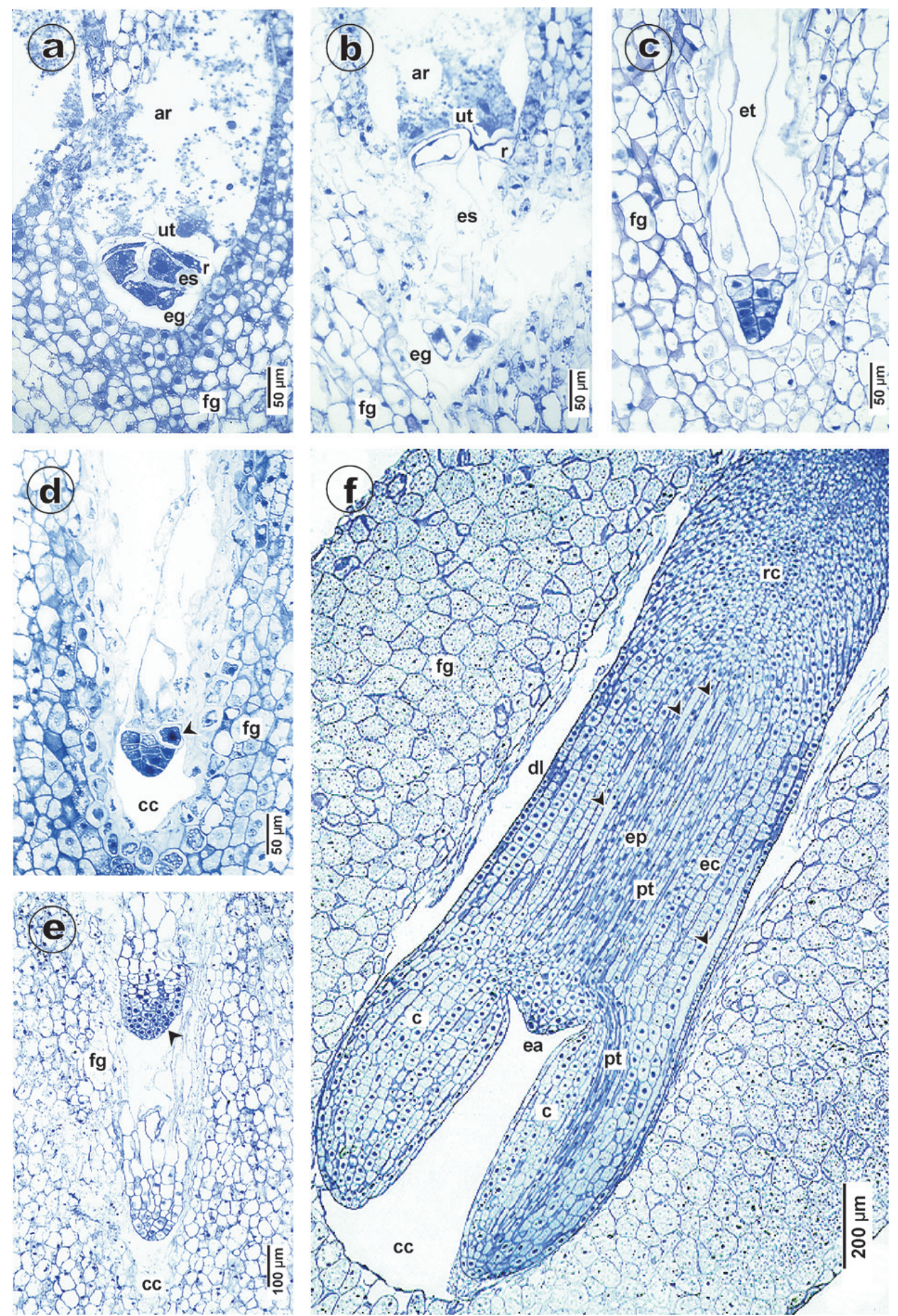

Figure 1. Development of embryo (ar: archegonium, fg: female gametophyte, ut: upper tier, r: rosette, es: embryonal suspensor, eg: embryonal group, et: embryonal tube, rc: root cap, ep: embryonic pith, ec: embryonic cortex, dl: dermal layer, ea: embryonic apex, c: cotyledons, pt: provascular tissue, cc: corrosion cavity). (a) Four-layer proembryo in the chalazal region of fertilized egg cell. June 8. (b) Elongation of embryonal suspensor and displacement of the embryonal group out of fertilized archegonium. June 8. (c) Formation of multicellular embryonal mass inside the corrosion cavity. June 8. (d) Globular embryonal mass: one of the embryonal units seems to be suppressed (marked with arrowhead). June 8. (e) Continuing development of non-differentiated embryo and appearance of simple polyembryony with the possible substitution of the more vigorous distal embryo (marked with arrowhead) for the less vigorous proximal one. June 17. (f) Differentiated embryo (arrowheads: elongated cells with an assumed secretory activity). July 30. Note: root meristem, column and pericolumn are not visible due to the oblique section. 


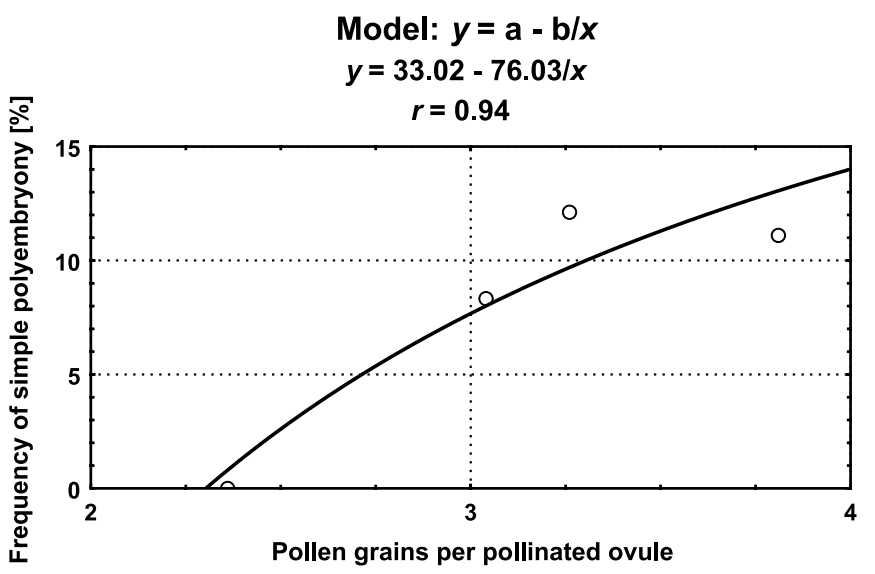

Figure 2. Correlation between the efficiency of pollination and percentage of fertilized ovules with simple polyembryony.

following three essential types of the abnormal-looking embryos were distinguished (Figs. 3a-3c):

(i) Embryos with an abnormal location in the corrosion cavity (Fig. 3a).

(ii) Embryos with apparent anatomical and cytological symptoms of degeneration (Fig. 3b).

(iii) Dwarfed embryos, retarded apparently in their growth (Fig. 3c).

Abnormal appearance and symptoms of degeneration were also characteristic of all the suppressed embryos from polyembryony. However, in some cases of simple polyembryony, the embryo with the most favourable position in the corrosion cavity had the attributes of abortion while the second, more distally situated embryo was larger and more vigorous (Fig. 1e). This fact supports the assumption that simple polyembryony offers the possibility of embryo replacement after degeneration.
In general, the proportion of the female gametophytes with complete degeneration of embryos was minimal in ovules with simple polyembryony, whereas the absence of viable embryos was much more frequent in cases of single fertilized archegonium per ovule.

As shown in Table II, complete degeneration of embryos occurred in 44.4-83.3\% of the fertilized ovules exposed to the open pollination (the minimum and maximum values were related to the clones marked as Š13 and M10, respectively), whereas after the controlled self-pollination the percentage of the fertilized ovules with the completely degenerated embryos was considerably higher: it ranged from $81.3 \%$ in M10 to $100.0 \%$ in the clone marked as Š13. The differences in percent complete degeneration between open pollination and self-pollination $(61.1 \%$ vs. $87.7 \%$ on average, respectively) were significant at $\alpha=0.01$ (Tab. III). When calculated for the total number of ovules (fertilized as well as unfertilized ones), all the resultant proportions were lower and the total differences changed due to the different success of fertilization in individual samples. On average, embryo degeneration reduced the expected potential full seed set by almost $40 \%$.

\section{DISCUSSION}

In various species of Larix, fusion of gametes and first divisions of zygote take place several weeks after pollination, a short time after relocation of engulfed pollen grains from the micropylar canal to the tip of nucellus. According to our observations, the estimated most frequent fertilization date occurs in early June.

The differences between the percentages of unfertilized ovules (especially between open pollination and self-pollination) might suggest the existence of some kind of a pre-zygotic incompatibility between pollen grains and the female gametophyte $[9,24,36,37]$. However, our results are mostly influenced by an occasional lack of pollination [31], whereas the
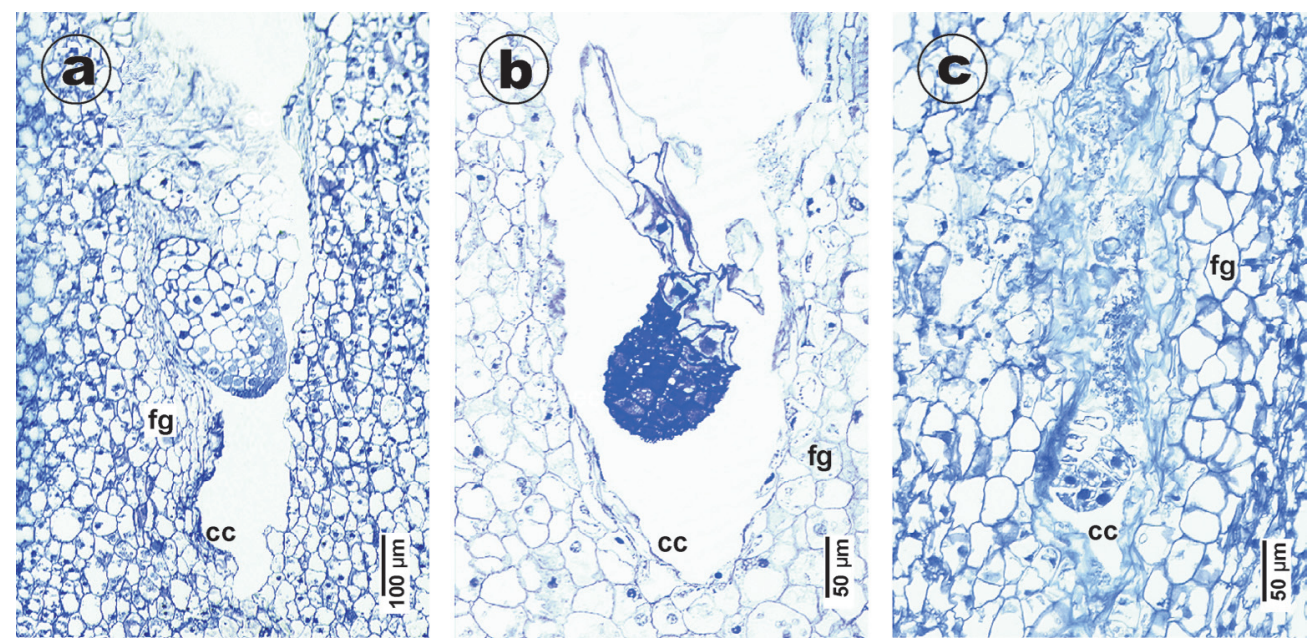

Figure 3. Appearance of degenerating embryos (fg: female gametophyte, cc: corrosion cavity). (a) Abnormally located and partially deformed embryo. June 17. (b) Degenerated embryo with darkly staining cells. June 22. (c) Abnormally small embryo retarded in its growth. June 17. 
Table II. Percentage of ovules with complete degeneration of embryos depending on mode of pollination and clone.

\begin{tabular}{|c|c|c|c|c|}
\hline \multirow[t]{2}{*}{ Pollination } & \multirow[t]{2}{*}{ Clone } & \multicolumn{2}{|c|}{ Proportion of ovules with the complete degeneration of embryos } & \multirow{2}{*}{$\begin{array}{l}\text { Unfertilized } \\
\text { ovules (\%) }\end{array}$} \\
\hline & & From fertilized ovules (\%) & From total number of ovules $(\%)$ & \\
\hline \multirow[t]{5}{*}{ Open } & M5 & 50.0 & 40.0 & 20.0 \\
\hline & M10 & 83.3 & 55.6 & 33.3 \\
\hline & $\check{S} 13$ & 44.4 & 28.3 & 36.4 \\
\hline & Š14 & 66.7 & 35.6 & 46.7 \\
\hline & Total & 61.1 & 39.9 & 34.1 \\
\hline \multirow[t]{5}{*}{ Self } & M5 & 91.7 & 28.2 & 69.2 \\
\hline & M10 & 81.3 & 51.7 & 36.4 \\
\hline & Š13 & 100.0 & 44.5 & 55.5 \\
\hline & Š14 & 77.8 & 32.4 & 58.3 \\
\hline & Total & 87.7 & 39.2 & 54.9 \\
\hline Total & & 74.4 & 39.5 & 44.5 \\
\hline
\end{tabular}

Table III. Results of testing the differences between the rates of fertilized ovules with complete degeneration of embryos depending on mode of pollination; $p_{1} ; p_{2}=$ rates of fertilized ovules with complete degeneration of embryos, $n_{1} ; n_{2}=$ sample sizes, $\varphi_{1} ; \varphi_{2}=$ transformed variables, $\varphi_{1}=\arcsin \sqrt{p_{1}} ; \varphi_{2}=\arcsin \sqrt{p_{2}}, t_{s}=$ test statistic of the equality of two percentages $\left(t_{s}=\left[\varphi_{1}-\varphi_{2}\right] / \sqrt{820.8 \cdot\left[1 / n_{1}+1 / n_{2}\right]}\right)$, $z_{0.05} ; z_{0.01}=$ critical values of normal distribution.

\begin{tabular}{lcccccc}
\hline Pollination & $p_{1} ; p_{2}$ & $n_{1} ; n_{2}$ & $\varphi_{1} ; \varphi_{2}$ & $t_{s}$ & $z_{0.05}$ & $z_{0.01}$ \\
\hline Open & $61.1 \%$ & 45 & 51.42 & & & \\
Self & $87.7 \%$ & 49 & 69.45 & & & \\
\hline
\end{tabular}

percentage of pollinated, but unfertilized, ovules is almost constant [34]. Therefore, the existence of a pre-zygotic incompatibility between ovules and self-pollinating pollen grains is not assumed and, most likely, the first fertilizing male gamete is derived from the first pollinating pollen grain, according to earlier data related to Douglas fir [39]. Conversely, recent data from Chinese authors [15] suppose the existence of post-pollination pollen selection in Larix principis-rupprechtii Mayr.

The phases of proembryogenesis, early embryogenesis and late embryogenesis are usually distinguished during the development of the zygotic embryo. However, analogous to the phases of mitotic cell division, older literature defines zygotic embryogenesis as prostage, metastage, anastage and telostage [29]. While the progression of proembryogenesis or prostage is usually quick, metastage or early embryogenesis has a markedly longer duration - nearly two weeks, or $36 \%$ of the total time of all the four phases, according to the last cited author. Our results support the investigations of Kosiński [18, 19], who found the most frequent disturbances and losses of developing embryos at the stage of the suspensor's expansion and the displacement of embryonal group into the corrosion cavity. On the other hand, the late embryogenesis (anastage and telostage) is characterized by the intensive quantitative growth and histogenesis $[1,12,23,29,38]$.
In the context of our results, an extremely high percentage of self-pollinated ovules with complete degeneration of embryos may be interpreted as the negative selection of undesirable genotypes as early as in the embryonal phase. It seems to be probable (concerning the poor pre-zygotic incompatibility) that the genetically undesirable pollen grains of Larix may be transported to the tip of nucellus, produce normal pollen tubes and participate in fertilization. Nevertheless, the percentage of fully developed seeds decreases due to the frequent embryo degeneration at the post-zygotic stages.

Since a high percentage of selfed-embryo abortion (and consequently, the significant decrease of the full seed proportion after self-fertilization) was ascertained in various species of Larix [4, 17, 19, 26, 28], this mechanism may be considered a reproductive strategy within this genus. It seems to be controlled by lethal and sublethal genes $[17,26]$ and may also be considered the most significant reason for the high outcrossing rates, estimated after genetic analyses of full-developed seeds $[2,3,6,11,20,27]$. On the other hand, embryo degeneration may also be relatively frequent after cross-pollination (e.g. in ovules which were exposed to the pollen grains from surrounding trees with a high degree of relatedness). Therefore, besides the maximal possible restraint of self-fertilization, the combinations of genotypes (clones) with a minimal degree of the mutual genetic relationship should be preferred in breeding populations and conversely, the combinations, in which the percentage of embryo degeneration is permanently high following consanguineous mating, should be eliminated. Such consistent selection might contribute to a significant increase in vital seed proportion and thus, to the successful breeding and enhanced economical effectiveness of the seed orchards of larch.

Acknowledgements: This paper is based on a part of the $\mathrm{Ph} . \mathrm{D}$. thesis (B. Slobodník: Analysis of the sexual reproduction in European larch - Larix decidua Mill.) supported financially by Slovak grant agency VEGA (grant number 1/7056/20). For the scholarship administration during the study program at the Department of Plant Physiology (University of Graz), the first author's thanks are due to Federal Ministry 
of Science and Traffic (Republic of Austria) and Austrian Academic Exchange Service (ÖAD). We thank to Daren J. Carlson, MSc. from the University of Minnesota for reading the English manuscript.

\section{REFERENCES}

[1] Allen G.S., Embryogeny and development of the apical meristems of Pseudotsuga. II. Late embryogeny, Am. J. Bot. 34 (1947) 73-80.

[2] Burczyk J., Kosiński G., Lewandowski A., Mating pattern and empty seed formation in relation to crown level of Larix decidua (Mill.) clones, Silva Fenn. 25 (1991) 201-205.

[3] Burczyk J., Nikkanen T., Lewandowski A., Evidence of an unbalanced mating pattern in a seed orchard composed of two larch species, Silvae Genet. 46 (1997) 176-181.

[4] Dieckert H., Einige Untersuchungen zur Selbststerilität und Inzucht bei Fichte und Lärche, Silvae Genet. 13 (1964) 77-86.

[5] Ekberg I., Eriksson G., Development and fertility of pollen in three species of Larix, Hereditas 57 (1967) 303-311.

[6] El-Kassaby Y.A., Jaquish B., Population density and mating pattern in western larch, J. Hered. 87 (1996) 438-443.

[7] Eriksson G., Temperature response of pollen mother cells in Larix and its importance for pollen formation, Stud. For. Suec. 63 (1968) $1-131$.

[8] Eysteinsson T., Greenwood M.S., Weber J., Management of a prototype indoor orchard for accelerated breeding of larch, College of Forest Resources, Orono, Maine, Research Bulletin 9 (1993) 1-18.

[9] Gelbart G., von Aderkas P., Ovular secretions as part of pollination mechanisms in conifers, Ann. For. Sci. 59 (2002) 345-357.

[10] Gilmore D.W., David A.J., Current trends in management practices for European larch in North America, Forest. Chron. 78 (2002) $822-829$.

[11] Gömöry D., Paule L., Inferences on mating system and genetic composition of a seed orchard crop in the European larch (Larix decidua Mill.), J. Genet. Breed. 46 (1992) 309-314.

[12] Grob J.A., Carlson W.C., Goodwin J.B., Salatas K.M., Dimensional model of zygotic Douglas-fir embryo development, Int. J. Plant Sci. 160 (1999) 653-662.

[13] Håkansson A., Seed development in Larix, Bot. Not. 113 (1960) $29-40$.

[14] Hall J.P., Brown I.R., Embryo development and yield of seed in Larix, Silvae Genet. 26 (1977) 77-84.

[15] Jia G.X., Shen X.H., Yang Y.M., Does the pollen recognition and selection exist in L. principis-rupprechtii? in: Pâques L.E. (Ed.), Improvement of larch (Larix sp.) for better growth, stem form and wood quality, INRA, Unité d'Amélioration, de Génétique et de Physiologie des Arbres forestiers, Olivet, France, 2002, pp. 222231.

[16] Keith C.T., Chauret G., Basic wood properties of European larch from fast-growth plantations in Eastern Canada, Can. J. For. Res. 18 (1988) 1325-1331.

[17] Kosiński G., Genetic load in empty seeds of European larch, Arbor. Kórnickie 26 (1982) 231-236.

[18] Kosiński G., Megagametogenesis, fertilization, and embryo development in Larix decidua, Can. J. Forest Res. 16 (1986) 1301-1309.

[19] Kosiński G., Empty seed production in European larch (Larix deci$d u a)$, For. Ecol. Manage. 19 (1987) 241-246.
[20] Lewandowski A., Burczyk J., Mejnartowicz L., Genetic structure and the mating system in an old stand of Polish larch, Silvae Genet. 40 (1991) 75-79.

[21] Li B., Wyckoff G.W., Breeding strategies for Larix decidua, L. leptolepis and their hybrids in the United States, For. Genet. 1 (1994) $65-72$.

[22] Owens J.N., Molder M., Sexual reproduction of Larix occidentalis, Can. J. Bot. 57 (1979) 2673-2690.

[23] Owens J.N., Morris S.J., Misra S., The ultrastructural, histochemical, and biochemical development of the post-fertilization megagametophyte and the zygotic embryo of Pseudotsuga menziesii, Can. J. For. Res. 23 (1993) 816-827.

[24] Owens J.N., Morris S.J., Catalano G.L., How the pollination mechanism and prezygotic and postzygotic events affect seed production in Larix occidentalis, Can. J. For. Res. 24 (1994) 917-927.

[25] Pâques L.E., Variabilité naturelle du mélèze. I. Mélèze d'Europe: bilan de 34 ans de tests comparatifs de provenances, Ann. Sci. For. 53 (1996) 51-67.

[26] Park Y.S., Fowler D.P., Effects of inbreeding and genetic variances in a natural population of tamarack (Larix laricina (Du Roi) $\mathrm{K}$. Koch) in Eastern Canada, Silvae Genet. 31 (1982) 21-26.

[27] Paule L., Gömöry D., Mating system in the seed orchards of European larch (Larix decidua Mill.), in: Baradat P., Adams W.T., Müller-Starck G. (Eds.), Population genetics and genetic conservation of forest trees, SPB Academic Publishing, Amsterdam, 1995, pp. 321-328

[28] Sato T., Mode of fertilization and its individual variation in Larix gmelinii var. japonica, Silvae Genet. 46 (1997) 146-151.

[29] Schopf J.M., The embryology of Larix, Ill. Biol. Monogr. 19 (1943) $1-97$.

[30] Shin D., Karnosky D.F., Factors affecting seed yield in Larix, J. Korean For. Soc. 84 (1995) 207-217.

[31] Slobodník B., Pollination success and full seed percentage in European larch (Larix decidua Mill.), J. For. Sci. 48 (2002) 271-280.

[32] Slobodník B., The early-spring development of male generative organs and abnormalities in pollen ontogenesis of European larch (Larix decidua Mill.), For. Genet. 9 (2002) 309-314.

[33] Slobodník B., Guttenberger H., Ovule, megaspores, and female gametophyte formation in Larix decidua Mill. (Pinaceae), Acta Biol. Cracow. Bot. 42 (2000) 93-100.

[34] Slobodník B., Guttenberger H., Pollination mechanism of European larch (Larix decidua Mill.), Biologia (Bratislava) 58 (2003) $95-102$.

[35] Šindelár J., Genetics and improvement of European larch (Larix decidua Mill.), Ann For. Zagreb 18 (1992) 1-36.

[36] Takaso T., Owens J.N., Effects of ovular secretions on pollen in Pseudotsuga menziesii (Pinaceae), Am. J. Bot. 81 (1994) 504-513.

[37] Takaso T., von Aderkas P., Owens J.N., Prefertilization events in ovules of Pseudotsuga: ovular secretion and its influence on pollen tubes, Can. J. Bot. 74 (1996) 1214-1219.

[38] von Aderkas P., Bonga J.M., Klimaszewska K., Owens J.N., Comparison of larch embryogeny in vivo and in vitro, in: Ahuja M.R. (Ed.), Woody Plant Biotechnology, Plenum Press, New York, 1991, pp. 139-155.

[39] Webber J.E., Yeh F.C.H., Test of the first-on, first-in pollination hypothesis in coastal Douglas-fir, Can. J. For. Res. 17 (1987) 63-68. 